JMPF Vol. 9 No. $4: 243-251$

ISSN-p : 2088-8139

ISSN-e : 2443-2946

DOI : $10.22146 /$ jmpf.44444

\title{
Analisis Perencanaan dan Ketersediaan Obat di Kabupaten dan Kota Provinsi Jawa Timur
}

\author{
Analysis of Planning and Availibility of Drug in Distric and Municipality of East Java Province
}

\author{
Digdo Suryagama ${ }^{1 *}$, Satibi ${ }^{2}$, Sumarni $^{3}$ \\ 1. Departemen Program Pascasarjana Magister Manajemen Farmasi, Fakultas Farmasi Universitas Gadjah Mada \\ 2. Fakultas Farmasi, Universitas Gadjah Mada \\ 3. Departemen Psikiatri, Fakultas Kedokteran Kesehatan Masyarakat dan Keperawatan, Universitas Gadjah Mada \\ Submitted: 25-03-2019 Revised: 11-05-2019 Accepted: 27-11-2019 \\ Korespondensi : Digdo Suryagama : Email : dito1285@gmail.com
}

\begin{abstract}
ABSTRAK
Masalah ketersediaan obat selalu terjadi pada tiap Kabupaten/ Kota setiap tahun. Penelitian terkait pengelolaan obat khususnya yang berkaitan dengan evaluasi ketersediaan obat dan nilai obat rusak/ kadaluarsa telah banyak dilakukan dalam sepuluh tahun terakhir. Hampir seluruhnya menemukan adanya permasalahan pada ketersediaan obat. Dirjen Farmalkes melaporkan bahwa persentase Ketersediaan Obat Nasional di Propinsi Jawa Timur pada tahun 2017 telah mencapai 96,55\% namun angka tersebut belum menggambarkan kondisi ketersediaan obat secara riil karena perhitungan tidak menggunakan data kuantitas obat. Penelitian ini bertujuan untuk menjelaskan kondisi riil ketersediaan 17 item obat-obat indikator nasional tahun 2017 di Propinsi Jawa Timur, serta mengidentifikasi masalah dan informasi seputar pengelolaan yang telah berjalan di tahun 2017. Penelitian ini adalah penelitian observasional yang bersifat deskriptif kuantitatif. Instrumen penelitian berupa lembar pengumpulan data ketersediaan 17 item obat tahun 2017 dan pedoman wawancara. Hasil penelitian menunjukan bahwa ketersediaan obat berada pada kondisi berlebih dengan rata-rata mencapai 22,5 bulan. Obat program yang diadakan langsung oleh Pemerintah Pusat sering mengalami kelebihan persediaan di tingkat Instalasi Farmasi Kabupaten/ Kota namun rata-rata persentase obat rusak/ kadaluarsa masih pada rentang yang cukup baik (0-3\%). Hal ini dapat disimpulkan bahwa ketersediaan obat di Propinsi Jawa Timur pada tahun 2017 dipengaruhi oleh sistem perencanaan, sistem pengadaan, ketersediaan obat di tingkat penyedia (suplayer), ketersediaan sistem informasi manajemen dan kebijakan daerah masing-masing.

Kata kunci: Evaluasi; Pengelolaan obat; Perencanaan obat; Ketersediaan obat
\end{abstract}

\section{ABSTRACT}

The problem of drug availability always occurs in District/Municipality every year. Research related to drug management, especially those related to the evaluation of drug availability and the value of damaged/expired drugs, has been carried out in the last ten years. Almost all the research found problems with the availability of the drugs. The Director General of Pharmacy and Medical Devices reported that the percentage of the availability of National Medicines in East Java in 2017 had reached $96.55 \%$, but had not yet described the condition of the availability of medicines in real terms because the calculation did not use data on drug quantity. This study aims to explain the real conditions for the availability of 17 items of national indicator drugs in East Java in 2017, as well as identify problems and information about management that has been running in 2017. This research is an observational research that is descriptive quantitative. The research instrument was in the form of data collection sheets for the availability of 17 drug items in 2017 and interview guidelines. The results showed that the availability of drugs was in excess conditions with an average of $\mathbf{2 2 . 5}$ months. Drug programs held directly by the Central Government often experience excess inventory at the Regency/City Pharmacy Department level but the average percentage of drugs damaged/expired is still in a fairly good range (0-3\%). It can be concluded that the availability of drugs in East Java Province in 2017 is influenced by the planning system, procurement system, availability of drugs at the provider level (supply), availability of management information systems and respective regional policies.

Keywords: Evaluation; Drug Management; Drug Planning; Drug Avaibility 


\section{PENDAHULUAN}

Obat sebagai salah satu unsur penting dalam upaya kesehatan, mulai dari upaya peningkatan kesehatan, pencegahan, diagnosis, pengobatan dan pemulihan sehingga harus diusahakan agar selalu tersedia pada saat dibutuhkan. Masalah ketersediaan obat selalu terjadi pada tiap Kabupaten/ Kota setiap tahun. Ketersediaan obat yang berlebih (overstock) dapat menyebabkan pemborosan anggaran dan berpotensi mengalami kadaluarsa atau kerusakan. Ketersediaan obat yang kurang (stockout) dapat menyebabkan terganggunya pelayanan kesehatan kepada masyarakat.

$$
\text { Penelitian Rosmania }{ }^{1}
$$

menyebutkan bahwa telah terjadi stockout di Kota Surabaya pada bulan Januari hingga oktober 2014 dengan nilai rata-rata 8,56\%. Penelitian Razak ${ }^{2}$ (2012) juga menyebutkan bahwa gudang farmasi Kota Surakarta masih memiliki tingkat ketersediaan obat yang berada pada level kurang untuk mensuplai beberapa puskesmas. Hasil penelitian Waluyo $^{3}$ (2015) menyebutkan bahwa tingkat ketersediaan obat di wilayah Papua Selatan sekitar $75 \%$ dengan persentase nilai obat rusak / kadaluarsa diatas 7\% sedangkan hasil penelitian Silvania, $\mathrm{dkk}^{4} \quad$ (2012) menyimpulkan bahwa tingkat ketersediaan obat di Kabupaten Sleman berada pada level aman (13 bulan) namun dengan persentase jumlah item obat rusak/ kadaluarsa 28,7\% di tahun 2010.

Studi ketersediaan obat di Era JKN telah banyak diteliti di fasilitas pelayanan kesehatan seperti puskesmas oleh Rosmania ${ }^{1}$ (2014), Razak $^{2}$ (2012), Waluyo 3 (2015) dan Silvania, $\mathrm{dkk}^{4}$ (2012) namun penelitian mengenai perencanaan dan ketersediaan obat di propinsi Jawa Timur belum dilakukan. Berdasarkan Laporan kinerja Dirjen Farmalkes $^{5}$ (2017), persentase ketersediaan obat dan vaksin di Puskesmas di Propinsi Jawa Timur telah melebihi angka target nasional yaitu 95,66\% (Target 85\%). Hal ini menjadi sebuah capaian yang sangat baik bagi Propinsi Jawa Timur, namun terdapat permasalahan pada cara perhitungan data ketersediaan obat dan vaksin. Oleh karena itu penelitian ini difokuskan untuk mengetahui kondisi riil ketersediaan 17 item obat-obat indikator nasional tahun 2017 di Propinsi Jawa Timur serta mengidentifikasi masalah dan informasi seputar pengelolaan yang telah berjalan di tahun 2017.

\section{METODE}

\section{Desain penelitian}

Penelitian ini merupakan penelitian deskriptif kualitatif dengan pendekatan studi kasus untuk mengevaluasi kegiatan pengelolaan obat pada tingkat Instalasi Farmasi Kabupaten dan Kota. Penelitian ini menggali untuk satu kasus dalam jangka waktu tertentu, dan mengumpulkan data dari berbagai sumber (observasi dokumen, laporan atau wawancara). Penelitian dilakukan di Propinsi Jawa Timur pada Tahun 2018.

\section{Sasaran dan subjek penelitian}

Sasaran penelitian ini berjumlah 38 (tiga puluh delapan) Kabupaten/Kota di Propinsi Jawa Timur. Subjek penelitian adalah Dinas Kesehatan atau Instalasi Farmasi Kabupaten/Kota sedangkan respondennya adalah Kepala Seksi, Kepala Instalasi Farmasi atau staff yang bertugas sebagai pengelola obat. Responden dipilih secara purposive sampling yaitu pengambilan responden dengan kriteria inklusi antara lain : pernah atau sedang terlibat dalam pengelola obat publik minimal 1 tahun, saat ini bertugas sebagai pengelola obat publik dan mengisi lembar pengumpulan data dengan lengkap. Kriteria eksklusi penelitian ini adalah data yang tidak terisi dengan lengkap dan tidak bersedia untuk diwawancarai.

\section{Instrumen penelitian}

Instrumen yang digunakan adalah lembar data ketersediaan obat (17 Obat kunci/ Keydrug), dan lembar data obat kadaluarsa/ rusak tahun 2017. Data ketersediaan terdiri dari stok awal tahun, pemasukan dan pemakaian dalam setahun. Hasil akhir ketersediaan obat akan diketahui tingkat kecukupan obat dengan cara membandingkan antara stok tersedia (stok awal ditambah 
Tabel I. Karakteristik Subjek/Responden

\begin{tabular}{ll}
\hline Karakteristik Responden & $\mathbf{N}(\mathbf{\%})$ \\
\hline Usia & $5(15.2)$ \\
20-30 Tahun & $23(69.7)$ \\
31-40 Tahun & $4(12.1)$ \\
41-50 Tahun & $1(3)$ \\
>50 Tahun & \\
Jenis Kelamin & $14(42.4)$ \\
$\quad$ Pria & $19(57.6)$ \\
$\quad$ Wanita & \\
Masa Kerja di Instalasi Farmasi & $14(42.4)$ \\
1-5 Tahun & $19(57.6)$ \\
$>5$ Tahun & \\
Latar Belakang Pendidikan & $6(18.2)$ \\
$\quad$ Non Farmasi & $19(57.6)$ \\
Diploma/ Sekolah Kejuruan Farmasi & $8(24.2)$ \\
Sarjana Farmasi/ Apoteker & \\
\hline
\end{tabular}

Sumber : Pengolahan data primer

pemasukan) terhadap pemakaian rata-rata bulanan. Berdasarkan Quick, dkk (2012) dan Kementerian Kesehatan (2006) dalam Carolien, dkk (2017), ketersediaan obat dinyatakan aman apabila tingkat kecukupan minimal $90 \%$ dari pemakaian tahunan dan tingkat ketersediaan termasuk aman jika tersedia untuk 12-18 bulan, kurang jika $<12$ bulan, berlebih jika ketersediaan $>18$ bulan dan kosong jika $<1$ bulan, tingkat nilai kadaluarsa obat pada gudang pusat dinyatakan baik apabila kurang dari 3\%.

Wawancara dilakukan kepada responden untuk mengidentifikasi masalah dan menggali informasi lebih mendalam terkait pengelolaan obat. Wawancara dilakukan dengan menggunakan ceklist sebagai pedoman wawancara.

\section{Ethical clearance}

Penelitian ini disetujui oleh Komite Etika Penelitian Medis dan Kesehatan (MHREC) Fakultas Kedokteran Universitas Gadjah Mada - Rumah Sakit Umum Dr. Sardjito Yogyakarta dengan nomor sertifikat Ref: KE / FK / 0924 / EC / 2018, tanggal 31 Agustus 2018.

\section{HASIL DAN PEMBAHASAN \\ Karakteristik Subjek/ responden}

Tabel I memberikan gambar proporsi responden yang terlibat dalam penelitian. Jumlah responden yang terlibat dalam penelitian sebanyak 33 orang dengan proporsi responden wanita $(57,6 \%)$ lebih banyak dibandingkan responden pria $(42,4 \%)$ dengan rentang usia responden terbanyak adalah 31 40 tahun (69,7\%). Masa kerja 57,6\% responden lebih dari 5 tahun dan $42,4 \%$ memiliki masa kerja 1-5 tahun. Pendidikan responden mayoritas adalah Diploma dan Sekolah Menengah Kejuruan Farmasi (57,6\%), sedangkan $24,2 \%$ responden sudah menempuh pendidikan hingga profesi Apoteker.

Hasil ini menggambarkan bahwa kualifikasi pendidikan pengelola obat pada Instalasi Farmasi Kab/Kota di Propinsi Jawa Timur masih perlu adanya peningkatkan karena masih terdapat daerah yang memiliki pengelola obat dengan kualifikasi pendidikan non farmasi. Kualifikasi pendidikan yang kurang atau tidak sesuai bidangnya dapat berdampak pada rendahnya kemampuan pemahaman petugas terhadap tugasnya 
Tabel II. Ketersediaan 17 Item Obat Indikator di Propinsi Jawa Timur Tahun 2017

\begin{tabular}{lc}
\hline \multicolumn{1}{c}{ Nama obat } & Nilai tengah Ketersediaan (bulan) \\
\hline Ketersediaan Obat & 25,5 \\
Albendazol 400mg & 23,9 \\
Amoxicillin 500mg & 22 \\
Amoxicillin Sirup & 22,1 \\
Deksametason 0,5mg & 23,3 \\
Diazepam 5mg/ml Injeksi & 17,5 \\
Epinefrin 0,1\% Injeksi & 19,6 \\
Fitomenadion Injeksi & 26,3 \\
Furosemid 40mg & 22,5 \\
Garam Oralit & 21 \\
Glibenclamid 5mg & 18,2 \\
Metformin 500mg & 23,3 \\
Kaptopril 25mg & 26,6 \\
Hidroklortiazid 25mg & 12,7 \\
MgSO4 20\% Injeksi & 28,6 \\
Metilergometrin Injeksi & 20,4 \\
Parasetamol & 23,4 \\
Tablet tambah darah & 22,5 \\
Rata-rata Ketersediaan obat Se- Propinsi & \\
\hline
\end{tabular}

Sumber : Pengolahan data primer

mengelola obat. Dampak lebih lanjut akibat rendahnya kemampuan pemahaman petugas adalah kegiatan pengelolaan obat yang belum sesuai dengan standar .

\section{Evaluasi Perencanaan Obat di Jawa Timur}

Ketersediaan obat dan jumlah obat rusak/ kadaluarsa dipengaruhi oleh perencanaan yang matang dan akurat. Hal ini disebutkan dalam hasil penelitian oleh Sunardi (2000) dalam Rahayu ${ }^{8}$ (2017) yang menyatakan bahwa perencanaan dapat mempengaruhi ketersediaan obat di IFK Murung Raya Propinsi Kalimantan Tengah. Tahap perencanaan menjadi pengaruh dominan terhadap tingkat persediaan obat yang ada di level Kabupaten.

Berdasarkan hasil wawancara bahwa seluruh Kabupaten/Kota di Jawa Timur melakukan perencanaan obat dilakukan oleh Tim teknis perencanaan obat yang dibentuk berdasarkan Surat Keputusan (SK). Tim teknis ini bertugas melakukan seleksi obat yang akan diadakan setiap tahun. Seleksi obat dilakukan berdasarkan Formularium Nasional dan Daftar Obat Esensial Nasional (DOEN). Sebagian Kabupaten/kota juga menggunakan Formularium Kabupaten/ Kota sebagai dasar seleksi obat. Seluruh Kota/ Kabupaten di Propinsi Jawa Timur menghitung kebutuhan obat menggunakan metode konsumsi sesuai dengan pelatihan teknis pengelolaan obat yang pernah diselenggarakan oleh Dinkes Propinsi Jawa Timur dan buku pedoman pengelolaan obat. Metode ini dianggap lebih mudah untuk diterapkan dan hasil perhitungan lebih cepat diperoleh.

Hasil penelitian ini sejalan dengan yang dilakukan oleh Rosmania (2014) bahwa perencanaan obat menggunakan metode konsumsi dengan rumus yang telah diatur oleh Dinas Kesehatan Kota Surabaya. Hasil penelitian Rismalawati dan Lestari ${ }^{9}$ (2015) menyebutkan metode perencanaan obat di Kabupaten Muna Barat tahun 2015 
menggunakan metode epidemiologi dari 10 besar penyakit yang ada di wilayah tersebut, namun terdapat masalah pada realisasi anggaran.

Penentuan anggota Tim teknis perencanaan obat di seluruh Kabupaten/kota di Jawa Timur selalu memasukkan dokter layanan primer di Puskesmas karena dokter sebagai penentu jenis dan jumlah obat yang akan dipakai di Puskesmas. Hal ini sejalan dengan penelitian Satibi, dkk ${ }^{10}$ (2018) dan Prabowo, dkk ${ }^{11}$ (2016) yang menyatakan adanya pengaruhi faktor dokter yang berada di unit layanan kesehatan terhadap ketersediaan obat di wilayah tersebut. Ketersediaan obat di Era JKN seperti saat ini sangat dipengaruhi oleh faktor dokter yang bertugas di Unit layanan Kesehatan. Hal ini dikarenakan dokter dapat mempengaruhi pola peresepan yang terjadi. Apabila terjadi mutasi dokter layanan primer dapat mempengaruhi pola peresepan. Pola peresepan dokter yang berubah dan bervariasi menyebabkan ketersediaan obat berubah pula bahkan dapat terjadi perubahan jenis obat yang tidak terpakai lagi.

Hasil wawancara juga menemukan bahwa Sistem Informasi Manajemen Logistik (SIMLO) seperti Excel, E-logistic atau lainnya telah diterapkan hampir diseluruh Jawa timur namun ternyata belum dapat memperkirakan waktu tunggu dan waktu kekosongan obat. Perencanaan yang dilakukan saat ini melalui mekanisme bottom up (usulan) dan jumlah obat yang diadakan disesuaikan dengan pagu anggaran yang tersedia. SIMLO yang digunakan juga belum dapat memprediksi jumlah penggunaan obat untuk tahun berikutnya, karena penggunaan obat bersifat fluktuatif khususnya kategori obat program dan obat vital esensial.

Hal ini sejalan dengan penelitian Kusmini, dkk (2016) yang menyebutkan adanya penurunan ketersediaan obat nasional sampai dengan $64,2 \%$ karena penerapan $E$ Purchasing. Penyebab utamanya adalah penggunaan usulan Rencana Kebutuhan Obat sebagai dasar penetapan lelang obat E-Katalog belum optimal sehingga ketersediaan obatobat E-Katalog tidak dapat memenuhi kebutuhan obat nasional. Rencana Kebutuhan Obat dengan metode yang digunakan saat ini belum dapat menghasilkan data angka kebutuhan yang akurat. Hal ini berarti ada proses perencanaan obat ditingkat daerah hingga pusat yang belum berjalan dengan baik.

Tabel II menunjukkan tingkat ketersediaan obat di Propinsi Jawa Timur di Tahun 2017. Rata-rata ketersediaan obat yang cukup tinggi di Jawa Timur yaitu 22,5 Bulan. Hasil ini menunjukan tingkat ketersediaan obat melebihi standar yakni sebesar 12-18 bulan. Hasil ini menggambarkan bahwa masih terjadi penumpukan persediaan yang terjadi di gudang Instalasi Farmasi. Hal ini dapat berdampak pada besarnya biaya pemeliharaan gudang untuk persediaan obat yang sebesar itu.

Hasil penelitian ini berbeda dengan penelitian Kusmini, dkk (2016) yang menyebutkan bahwa tingkat ketersediaan obat di wilayah Propinsi Jawa Tengah pada tahun 2015 hanya sebesar 58,7\% di level aman, sedangkan sisanya $(41,3 \%)$ berada pada level kurang. Perubahan sistem pengadaan obat secara sistem E-Purchasing menjadi salah satu penyebabnya.

Tabel III menunjukan 5 obat dengan tingkat ketersediaan berlebih dan kurang pada obat Hidroclortiazid, Amoxicillin, Albendazol, Dexamethason dan Furosemid. Hasil pada tabel III juga menunjukan kondisi obat program seperti Albendazol, garam oralit dan tablet tambah darah termasuk dalam jenis obat yang sering mengalami persediaan berlebihan. Pengadaan obat program pada tahun tersebut diselenggarakan langsung oleh Kementerian Kesehatan (pusat). Dinas Kesehatan Kabupaten/Kota hanya menerima kedua obat tersebut berdasarkan perhitungan proporsi distribusi obat yang ditentukan oleh pusat maupun Propinsi. Dampaknya dapat membuat tingkat ketersediaan di daerah meningkat tinggi. Hal ini mungkin juga terjadi pada obat-obat program lainnya seperti 
Tabel III. Persentase Kejadian Overstok dan Stockout di Propinsi Jawa Timur Tahun 2017

\begin{tabular}{lc}
\hline \multicolumn{1}{c}{ Nama Obat } & Persentase Jumlah $\mathbf{K a b} /$ kota yang mengalami \\
\hline $\mathbf{5}$ Besar Obat paling sering mengalami kelebihan persediaan $(>\mathbf{1 8}$ Bulan) \\
Hidroklortiazid & $82,1 \%$ \\
Amoxicillin 500mg & $78,1 \%$ \\
Albendazol 400mg & $74,2 \%$ \\
Dexamethason 0,5mg & $72,7 \%$ \\
Furosemid & $66,7 \%$ \\
$\mathbf{5}$ Besar Obat paling sering mengalami kekurangan (<6 Bulan) & \\
Diazepam 5mg/mL Injeksi & $23,7 \%$ \\
MgSO4 & $21,1 \%$ \\
Fitomenadion Injeksi & $15,8 \%$ \\
Epinefrin 0,1\% Injeksi & $7,9 \%$ \\
Parasetamol & $5,3 \%$ \\
Obat Program Pemerintah paling sering mengalami kelebihan persediaan (>18 Bulan) \\
Albendazol 400 mg & $74,2 \%$ \\
Tablet Tambah darah & $63,3 \%$ \\
Garam oralit & $59,4 \%$ \\
\hline
\end{tabular}

Sumber : Pengolahan data primer

program Tubercolosis (TBC), Kusta, HIV, dan Filariasis yang tidak teramati pada penelitian ini.

Kebijakan pemerintah untuk menggunakan E-Purchasing dalam proses pengadaan obat ternyata mempengaruhi ketersediaan obat di Jawa Timur. Hasil wawancara menemukan bahwa terjadi kelangkaan beberapa suplai obat E-Purchasing sejak Tribulan ketiga tahun 2017. Hambatan terjadi pada keterlambatan suplai obat dari produsen dan inflasi mempengaruhi ketersediaan obat E-Purchasing ${ }^{12}$. Hal ini tidak sejalan dengan penelitan Sutriatmoko, dkk ${ }^{13}$ (2015) bahwa Pengadaan obat dengan EPurchasing seharusnya dapat meningkatkan efisiensi pengadaan. Penelitan Sutriatmoko, dkk (2015) menyebutkan terdapat pengaruh positif E-Purchasing obat terhadap efisiensi pengadaan obat. Penelitian Alfenia, dkk ${ }^{14}$ (2016) menyebutkan bahwa faktor dari supplier (spesifikasi, ketersediaan produk, waktu kirim), dan faktor proses pengadaan ( $E$ Catalogue, E-Procurement, perencanaan) berpengaruh signifikan terhadap ketersediaan obat.
Penolakan pesanan obat E-purchasing oleh penyedia serta keterlambatan atau ketidaksesuaian jumlah pengiriman obat oleh distributor berdampak pada kondisi persediaan Kabupaten/ Kota menipis. Pada Tahun 2017, Parasetamol menjadi salah satu obat yang paling sering mengalami keterlambatan pengiriman bahkan penolakan pesanan. Obat tersebut merupakan obat esensial yang paling sering digunakan di Faskes tingkat pertama. Obat-obat vital untuk kebutuhan UGD (Vital Essensial) seperti Diazepam injeksi, Epinefrin injeksi, Fitomenadion injeksi, dan $\mathrm{MgSO} 4$ injeksi juga mengalami keterlambatan suplai. Hal ini dipengaruhi oleh faktor jumlah kasus gawat darurat yang terjadi karena sangat fluktuatif dan tidak dapat diprediksi (unpredictable)..

Hasil wawancara menyebutkan salah satu solusi untuk meminimalkan kejadian stockout adalah membuat kebijakan untuk melakukan pengadaan obat melalui mekanisme non E-Purchasing (mekanisme Pengadaan Langsung, Lelang Umum ataupun E-Tendering). Mekanisme pengadaan seperti ini membutuhkan proses lebih lama dan rumit 
Tabel IV. Persentase Nilai Obat Rusak dan Kadaluarsa di Propinsi Jawa Timur Tahun 2017

\begin{tabular}{cc}
\hline Persentase nilai Obat Rusak dan Kadaluarsa & Persentase Jumlah Kab/Kota yang mengalami \\
\hline$>6 \%$ & 5,3 \\
$3-6 \%$ & 13,1 \\
$0-3 \%$ & 81,6 \\
\hline
\end{tabular}

Sumber : Pengolahan data primer

khususnya dalam pembuatan berkas pertanggungjawaban keuangan. Hal tersebut menyebabkan proses pengadaan non E-Purchasing ini tidak banyak yang melakukannya.

Hasil wawancara juga menyebutkan bahwa pengadaan obat Non E-Purchasing biasanya biasanya dilakukan pada akhir tahun anggaran (tribulan tiga atau empat) karena menunggu kepastian akhir kesanggupan penyedia obat E-Catalogue. Hal ini berdampak pada tingkat ketersediaan obat tiba-tiba melambung tinggi diakhir tahun anggaran. Latifah, dkk ${ }^{15}$ (2018) menyebutkan bahwa Negara-negara berkembang mengalami kecenderungan tingkat ketersediaan obat yang rendah. Perbaikan perlu dilakukan dengan kebijakan pemerintah terkait peningkatan akses obat dan pengaturan harga obat.

\section{Evaluasi Nilai Obat Rusak dan Kadaluarsa di Jawa Timur}

Tabel IV menggambarkan tingkat jumlah obat rusak maupun kadaluarsa yang diukur dari persentase nilai kerugian obat di Propinsi Jawa Timur. Sebagian besar daerah $(81,6 \%)$ menghasilkan persentase nilai obat rusak dan kadaluarsa dalam tingkat cukup baik, sedangkan persentase nilai obat rusak/kadaluarsa yang cukup tinggi hanya terjadi pada sebagian kecil daerah. Nilai tersebut masih cukup baik dibandingkan dengan penelitian Waluyo (2015) yang menyebutkan persentase nilai obat rusak / kadaluarsa di wilayah Papua Selatan diatas 7\% sedangkan penelitian Silvania, dkk (2012) menyimpulkan bahwa persentase jumlah item obat rusak/ kadaluarsa di Kabupaten Sleman mencapai 28,7\% di tahun 2010.
Hasil persentase nilai obat rusak dan kadaluarsa pada dua kabupaten/kota diperoleh menjadi tinggi karena merupakan kumpulan nilai obat kadaluarsa dan rusak sejak periode tahun anggaran 2015 hingga 2017 yang tidak bisa dibedakan dan belum dimusnahkan. Pemusnahan terhadap obat rusak atau kadaluarsa baru dilakukan oleh Dinas Kesehatan apabila jumlahnya telah mencapai tingkat berat tertentu atau kapasitas gudang mulai penuh. Rata-rata pemusnahan dilakukan 3 tahun sekali dan dilakukan pada awal tahun.

Hasil wawancara menyebutkan terdapat beberapa solusi untuk mengurangi jumlah dan jenis obat yang kadaluarsa. Solusi pertama adalah dengan melakukan "Push Out dropping" yaitu menyalurkan (droping) obat dalam jumlah relatif jauh lebih banyak daripada jumlah permintaan dari LPLPO kepada Puskesmas. Umumnya dilakukan terhadap obat-obat yang mendekati masa kadaluarsa (3 Bulan sebelum kadaluarsa). Obat-obat tersebut mayoritas adalah kelompok obat fast moving/ middle moving. Solusi kedua dengan menghimbau puskesmas agar melakukan relokasi obat antar puskesmas kepada puskesmas lain yang lebih membutuhkan.

Solusi ketiga adalah meningkatkan penggunaan obat-obat yang hampir kadaluarsa tersebut melalui mekanisme substitusi obat dengan kelas terapi yang sama agar obat yang hampir kadaluarsa bisa lebih cepat terpakai. Contoh penerapan solusi ini misalkan terdapat obat ibuprofen tablet yang hampir kadaluarsa maka resep parasetamol disubstitusi dengan ibuprofen untuk pasien dewasa. Solusi terakhir yang dapat dilakukan 
adalah retur dan tukar obat. Solusi ini jarang dilakukan karena tidak semua PBF menerima retur obat. Dinas Kesehatan melakukan retur dan penukaran untuk mendapatkan obat yang masa kadaluarsa lebih panjang atas dasar perjanjian kontrak kedua pihak. Perjanjian ini harus masukkan dalam klausul Surat Perjanjian Pengadaan Obat sebagai bentuk jaminan purna jual karena terkadang PBF memberikan obat dengan masa kadaluarsa pendek $(<24$ bulan untuk sediaan cair atau $<12$ bulan untuk sediaan serum). Seluruh solusi tersebut menjadi faktor yang dapat mempengaruhi persentase rata-rata nilai obat rusak/ kadaluarsa di tingkat Instalasi Farmasi menjadi rendah (mendekati nol) waaupun tingkat ketersediaan obatnya cukup tinggi pada akhir tahun.

Kelengkapan data yang dikumpulkan menjadi kendala dalam penelitian ini. Data yang berhasil dikumpulkan secara lengkap oleh peneliti berasal dari 33 kab/kota. Data dari 5 kab/kota tidak berhasil dikumpulkan dengan lengkap karena terkendala birokrasi perijinan penelitian.

\section{KESIMPULAN}

Tingkat Ketersediaan obat Kabupaten/Kota di Propinsi Jawa Timur pada posisi akhir tahun 2017 mengalami kelebihan persediaan dan sebagian kecil mengalami kekurangan persediaan. Obat program yang diadakan langsung oleh Pemerintah Pusat sering mengalami kelebihan persediaan. Kelebihan persediaan yang terlalu tinggi berdampak pada meningkatnya persentase obat rusak/kadaluarsa pada tahun-tahun berikutnya dan pemanfaatan anggaran belanja obat yang kurang efisien. Rata-rata persentase obat rusak/ kadaluarsa masih pada rentang yang cukup baik karena Dinas Kesehatan mempunyai solusi kebijakan masing-masing untuk meminimalkan jumlah dan jenis obat kadaluarsa. Ketersediaan obat Kabupaten/Kota di Propinsi Jawa Timur pada tahun 2017 dan persentase nilai obat rusak/ kadaluarsa dipengaruhi oleh sistem perencanaan obat, sistem pengadaan, ketersediaan obat di tingkat penyedia, ketersediaan sistem informasi manajemen dan kebijakan daerah masing-masing.

\section{SARAN}

Saran untuk penelitian berikutnya adalah sebaiknya mengevaluasi tren tingkat ketersediaan obat perbulan dalam periode waktu 1 tahun anggaran. Hasil yang diperoleh dapat menggambarkan kondisi lebih nyata terkait ketersediaan obat setiap bulannya. Evaluasi juga perlu dilakukan sampai tingkat Subunit pelayanan yaitu Puskesmas.

\section{UCAPAN TERIMAKASIH}

Ucapan terimakasih disampaikan kepada BPPSDMK Kementerian Kesehatan RI yang telah membiayai penelitian ini sepenuhnya.

\section{DAFTAR PUSTAKA}

1. Rosmania FA., Supriyanto S. Analisis Pengelolaan Obat Sebagai Dasar Pengendalian Safety Stock pada Stagnant dan Stockout Obat. J Adm Kesehat Indones. 2015;3(1):1-10.

2. Razak A., Pamudji G., Harsono M. Efficiency Analysis Of Drug Management On Distribution And Usage Level In Community Health Centers. J Manaj Dan Pelayanan Farm. 2012;2(3):186-194.

3. Waluyo YW., Athiyah U., Rochmah TN. Analysis of Factor Influencing public Public Drug management in District Pharmacy Installation (Study in Southern Papua Area). J Ilmu Kefarmasian Indones. 2015;13(1):94-101.

4. Silvania A., Hakim L., Satibi. Evaluasi Kesesuaian Antara Perencanaan dan Realisasi Penerimaan Obat di Puskesmas rawat Inap Se-Kabupaten Sleman tahun 2008-2010. J Manag Pharm Pract. 2012;2(2):90-94.

5. Direktorat Jenderal Kefarmasian dan Alkes. Laporan Kinerja Direktorat Jenderal Kefarmasian dan Alat Kesehatan Tahun 2017. 2018.

6. Quick JD, Embrey M, Dukes G, et al., Managing Access to Medicine and Health 
Technologies. USA: Management Science for Health; 2012.

7. Carolien I., Fudholi A., Endarti D. Evaluation Medicine Availability Before and After NHI Implementation at Health Centers in Keerom District, Papua Province. J Manag Pharm Pract. 2017;7(1):31.

8. Rahayu TS. Evaluasi Perencanaan dan Ketersediaan Obat di Instalasi Farmasi Dinas Kesehatan Kabupaten Murung Raya Provinsi Kalimantan Tengah Tahun 2013-2015. Tesis. Universitas Gadjah Mada Yogyakarta. 2017.

9. Rismalawati., Lestari H. Studi Manajemen Pengelolaan Obat di Puskesmas Lawa Kabupaten Muna Barat Tahun 2015. J Ilm Mhs Kesehat Masy. 2017;1(3).

10. Satibi, Ranowijaya., Aswandi., Bermalam J., Pamudji G. Factor Analysis that Influence the Availability of Drugs During JKN Era. Indones J Pharm. 2018;29(1):37.

11. Prabowo P., Satibi., Pamudji G. Analisis Faktor - Faktor Yang Mempengaruhi
Ketersediaan Obat Di Era Jkn Pada Rumah Sakit Umum Daerah. J Manaj Dan Pelayanan Farm. 2016;6:6.

12. Kusmini., Satibi., Suryawati S. Evaluasi Pelaksanaan E-Purchasing Obat Pada Dinas Kesehatan/ Kabupaten Kota di Jawa Tengah 2015. J Manaj Dan Pelayanan Farm. 2016;6(4):277-287.

13. Sutriatmoko., Satibi., Puspandari DA. Analisis Penerapan E-Procurement Obat Dengan Prosedur E- Purchasing Berdasar E-Catalogue Di Dinas Kesehatan Kabupaten/Kota Di Jawa Tengah. J Manaj Dan Pelayanan Farm. 2015;5(4):8.

14. Alfenia DD. Ketersediaan Obat Dan Faktor-Faktor Yang Mempengaruhi Ketersediaan Obat Pada Era Jkn Di Rumah Sakit Umum Daerah Di Provinsi D.I Yogyakarta. 2016.

15. Latifah E., Kristina SA., Sri Suryawati S., Satibi S S. Overview of Drug Availability and Influencing Factors in Several Low, Lower and Upper- Middle Countries: A Systematic Review. Syst Rev Pharm. 2018;10(1):67-72. 